Review

\title{
Allanblackia Oil: Phytochemistry and Use as a Functional Food
}

\section{Sara L. Crockett}

Department of Pharmacognosy, Institute of Pharmaceutical Sciences, Universitaetsplatz 4/I, University of Graz, Graz 8010, Austria; E-Mail: sara.crockett@uni-graz.at; Tel.: +43-316-380-5525; Fax: $+43-316-380-9860$

Academic Editor: Maurizio Battino

Received: 27 July 2015 / Accepted: 21 August 2015 / Published: 15 September 2015

\begin{abstract}
The consumption and commercial exploitation of Allanblackia (Clusiaceae) seed oils is of current interest. The favorable physicochemical characteristics of Allanblackia oil (solid at room temperature; high stearic acid content) lend food products that contain it (i.e., vegetable-based dairy products, ice cream, spreads) health advantages over others that contain higher levels of lauric, myristic, and/or palmitic acids, which can increase blood cholesterol levels. Such considerations are important for individuals prone to cardiovascular disease or with hypercholesterolemia. Domestication projects of several Allanblackia species in tropical Africa are underway, but wildcrafting of fruits to meet the seed demand still occurs. Proper species authentication is important, since only authenticated oil can be deemed safe for human consumption. The chemical constituency of Allanblackia seed oils, and potential roles of these phytochemicals in preventive strategies (e.g., as part of a healthy diet) and as pharmacological agents used to treat chronic disease were examined in this review. The primary and secondary metabolite constituency of the seed oils of nearly all Allanblackia species is still poorly known. The presence, identity, and quantity of potentially bioactive secondary metabolites in the seed oils, and pharmacological testing of isolated compounds were identified as important directions for future research.
\end{abstract}

Keywords: Allanblackia; Clusiaceae; oil; seed; functional food; saturated fatty acid; stearic acid; oleic acid 


\section{Introduction}

On a worldwide scale, the supplies and consumption of oils and fats have generally been described in terms of 17 commodity oils, four that originate from animals and thirteen that are derived from plants, namely soybean, palm, rape/canola, sunflower, coconut, palmkernel, cottonseed, groundnut (peanut), olive, corn, sesame, rice bran, and flaxseed oil. During recent decades, as information about the negative health effects of animal fat consumption has accumulated, higher consumption rates of fats and oils from plants have been documented. In addition, the demand for oils and fats from alternative plant sources has steadily increased, driven by several factors including: the demand for food from a steadily growing population with more financial resources, demand for biodiesel (food-fuel debate), price increase of some oils due to the rising costs of agricultural production, storage, and transport, fluctuations in oilseed yield due to poor climatic conditions in many parts of the world, and speculation [1]. In particular, due to the fact that more than $90 \%$ of the world's biodiesel is currently produced from edible vegetable oils, significant research efforts are being invested in the discovery of alternative plant-based oil (both edible and non-edible) sources [2].

At the same time, an ever increasing number of consumers believe that foods contribute directly to their health and this has, in turn, driven food producers and manufacturers to produce foods that not only satisfy hunger and provide valuable nutrients, but can be used as preventative medicine to improve both physical and mental health [3]. The World Health Organization (WHO) and the Food and Agriculture Organization of the United Nations (FAO) have described diets and lifestyle habits that can contribute to the development of such chronic diseases as cancer, osteoporosis, coronary heart disease, obesity, periodontal disease, and type 2 diabetes [4]. Therefore, changes in diet and potentially the inclusion of functional foods could lead to the prevention of chronic diseases. As a growing market, functional foods have steadily increasing economic importance. With regard to plant-based oils as functional foods, information on both the primary (i.e., triacylglycerols and fatty acids) and secondary (e.g., phosopholipids, sterols, tocopherols, carotenoids, phenolics) metabolites in these oils is of interest.

While numerous reviews about bioactive components in the common commodity oils are available, the literature describing primary and secondary constituents in new, alternative, edible plant-based oils is still sparse. Additionally, few studies have specifically focused on the roles of these phytochemicals in preventive strategies (e.g., associated with increased intake as part of a healthy diet) or as pharmacological agents used in the treatment of chronic disease. The current review summarizes information known about the oils expressed from seeds of species of Allanblackia Oliv. ex. Bentham (Clusiaceae), a genus that is currently the focus of a high degree of attention with regard to its consumption and commercial exploitation.

\section{Results and Discussion}

\subsection{Botanical Description and Geographic Distribution}

The genus Allanblackia is a member of the flowering plant family Clusiaceae Lindley (also Guttiferae Juss. nom. alt. et cons., order Malpighiales), which includes 14 genera and nearly 600 species of trees or shrubs that are primarily distributed in tropical regions of the world. The family comprises the

subfamilies Clusieae Choisy (Clusia L., Chrysochlamys Poepp., Dystovomita (Engler) D'Arcy, Tovomita Aublet, Tovomitopsis Planchon \& Triana), Symphonieae (Lorostemon Ducke, Montrouziera 
Planchon \& Triana, Moronobea Aublet, Pentadesma Sabine, Platonia Martius, Symphonia L., Thysanostemon Maguire), and Garcinieae Choisy (Allanblackia, Garcinia L.). Species belonging to the Garcinieae are dioecious and share several morphological characters including the possession of colleters (clusters of mucilaginous secretory hairs), capitate stigmas, frequently non-scaly buds and anthers that open toward the gynoecium, as well as fruits that are indehiscent and baccate, whereby the testa and endocarp are at least partially fused [5]. Sweeney [6] and Ruhfel et al. [7] have suggested that Allanblackia should be combined with Garcinia on the basis of the results of multigene phylogenetic analyses, but the former generic name has been thus far been retained. Both Allanblackia and Garcinia (mangosteen) contain species with oily seeds that are of potential commercial interest, because two component fatty acids (stearic and oleic) together comprise up to $95 \%$ of the total fatty acids present in the seed oil [8].

Nine species of Allanblackia have been recognized, all of which are restricted in their natural distribution to tropical Africa, according to Bamps et al. [9]: A. gabonensis (Pellegr.) Bamps, A. floribunda Oliv., A. kimbiliensis Spirl, A. kisonghi Vermoesen, A. marienii Staner, A. parviflora A.Chevalier, A. stanerana Exell \& Mendonça, A. stuhlmannii Engl., and A. ulugurensis Engl. Three of these species (A. floribunda, A. parviflora, and A. stuhlmannii) are of considerable commercial interest (see Figure 1).

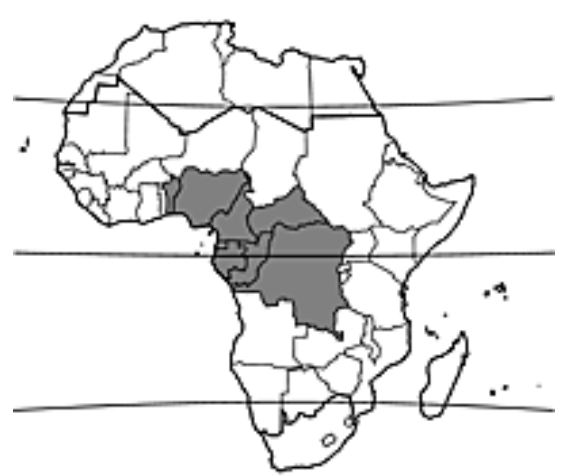

(a)

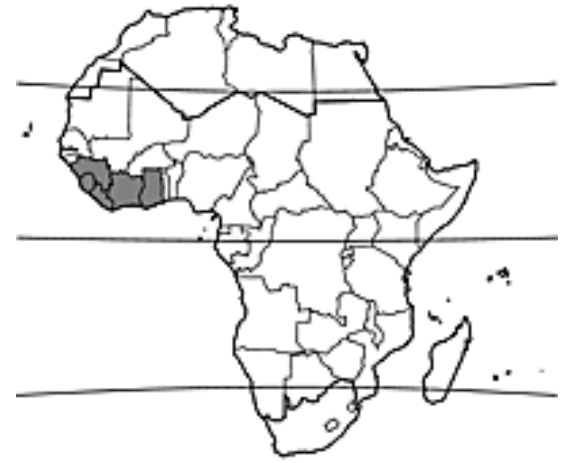

(b)

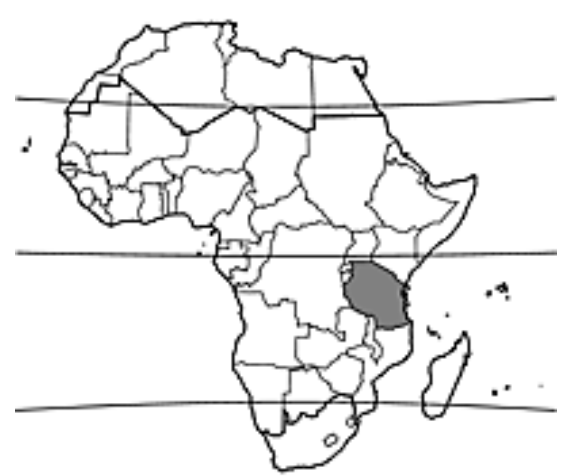

(c)

Figure 1. Native geographic distributions of (a) Allanblackia floribunda; (b) A. parviflora; and (c) A. stuhlmannii. Maps reprinted with permission from: PROTA (Plant Resources of Tropical Africa/Ressources végétales de l'A frique tropicale), Wageningen, The Netherlands. http://www.prota4u.org.

Allanblackia floribunda (vegetable tallow tree) is a tree species that is commonly distributed in the moist tropical forest zone that extends from Nigeria east to the Central African Republic and the eastern Democratic Republic of the Congo, then south to northern Angola and eastward to Uganda [10]. Allanblackia parviflora (also referred to as vegetable tallow tree) has been frequently confused with A. floribunda due to their high degree of vegetative morphological similarity. Both are evergreen trees that, when mature, can attain a height of up to $30 \mathrm{~m}$ and a trunk diameter of $80 \mathrm{~cm}$; can have reddish-brown bark with small, irregular scales; possess opposite, simple, entire, glabrous, estipulate leaves with short $(\mathrm{ca} .1 \mathrm{~cm})$ petioles; have unisexual, regular, five-merous, pinkish to reddish flowers; and large, ellipsoid, berry-like fruits with at least 40 and up to 100 seeds (Figure 2). The male flowers of A. floribunda, however, have deeply folded disk glands and longer $(3-8 \mathrm{~cm})$ pedicels, as compared to male flowers of 
A. parviflora, which have smooth or slightly folded glands and shorter $(1-3 \mathrm{~cm})$ pedicels. In addition, the distributional areas of the species rarely overlap in nature, with trees of A. parviflora primarily occurring in the forested zone that extends from Guinea and Sierra Leone to Ghana [11].
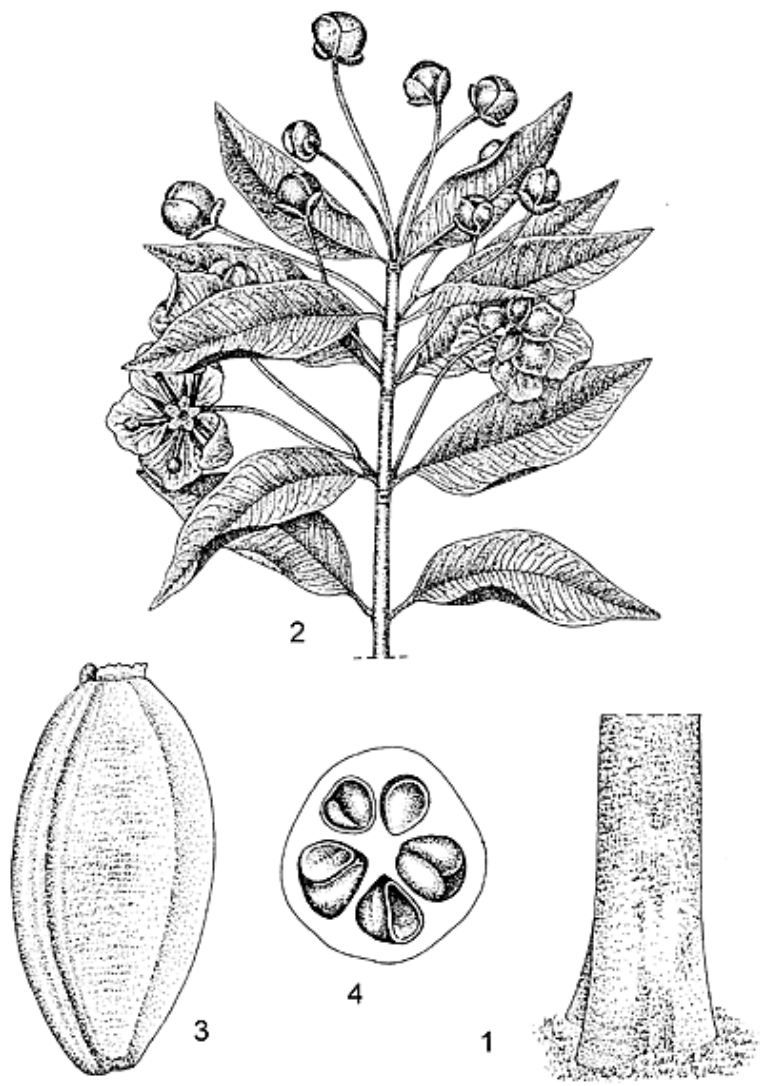

(a)

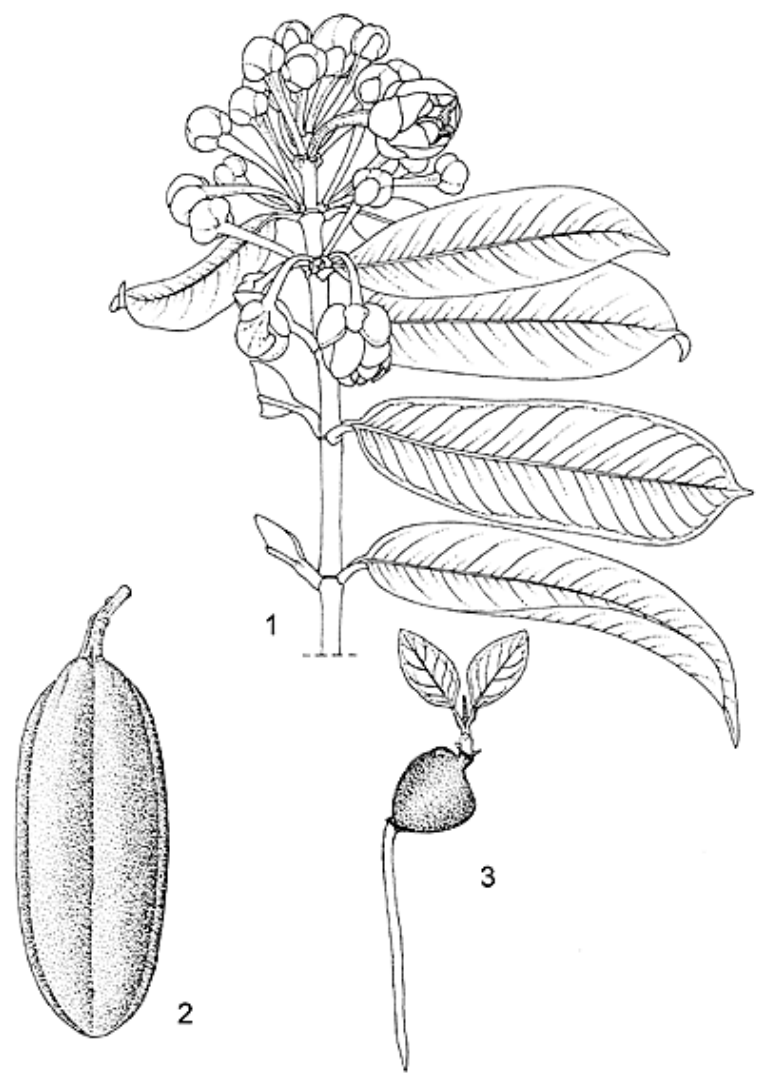

(b)

Figure 2. Line drawings detailing characteristic botanical features of (a) Allanblackia floribunda (1, base of bole; $\mathbf{2}$, flowering twig; 3, fruit; and 4, fruit in cross section showing seeds); and (b) A. parviflora (1, flowering twig; 2, fruit; and 3, seedling). Line drawings reprinted with permission from: PROTA (Plant Resources of Tropical Africa/Ressources végétales de l'Afrique tropicale), Wageningen, The Netherlands. http://www.prota4u.org.

Allanblackia stuhlmannii (in Swahili: Mkange), a species endemic to Tanzania, is distributed from Tanga in the North-East Highlands to the Iringa Region in the Southern Highlands, throughout the Eastern Arc Mountains, and occurs in mid-elevation evergreen sub-montane and montane forests. These evergreen trees can attain a mature height of up to $45 \mathrm{~m}$, but have a more slender trunk $(\mathrm{ca} .65 \mathrm{~cm}$ in diameter); dark grey to black bark that is smooth or rarely flaking with square scales; have opposite, simple, entire, glabrous, estipulate leaves with longer $(1-2 \mathrm{~cm})$ petioles; unisexual, regular, five-merous, cream to reddish fragrant flowers; and large, oblong to globose or cone-shaped berry-like fruits with at least 60 and up to 140 seeds [12] (Figure 3). See Table 1 for a comparison among the main botanical characteristics of the three species. 


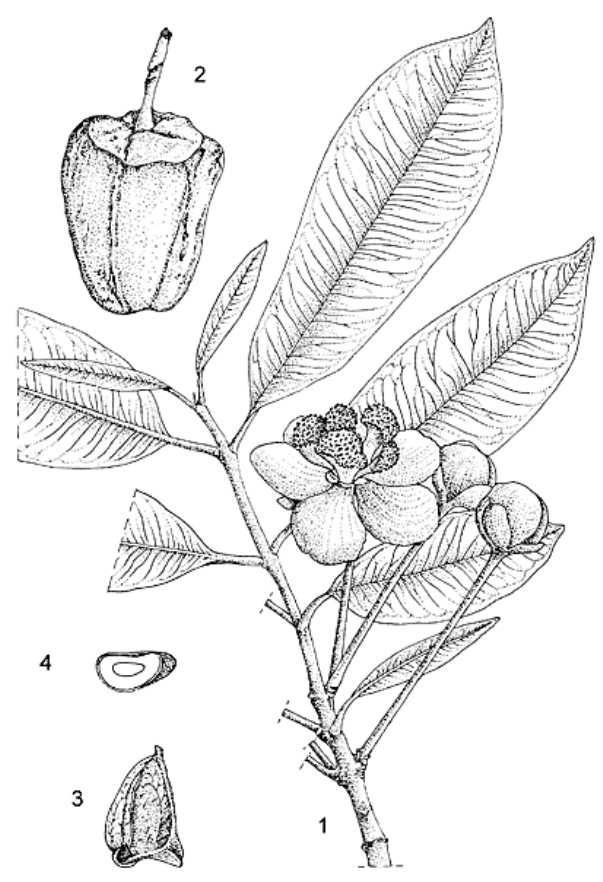

(a)

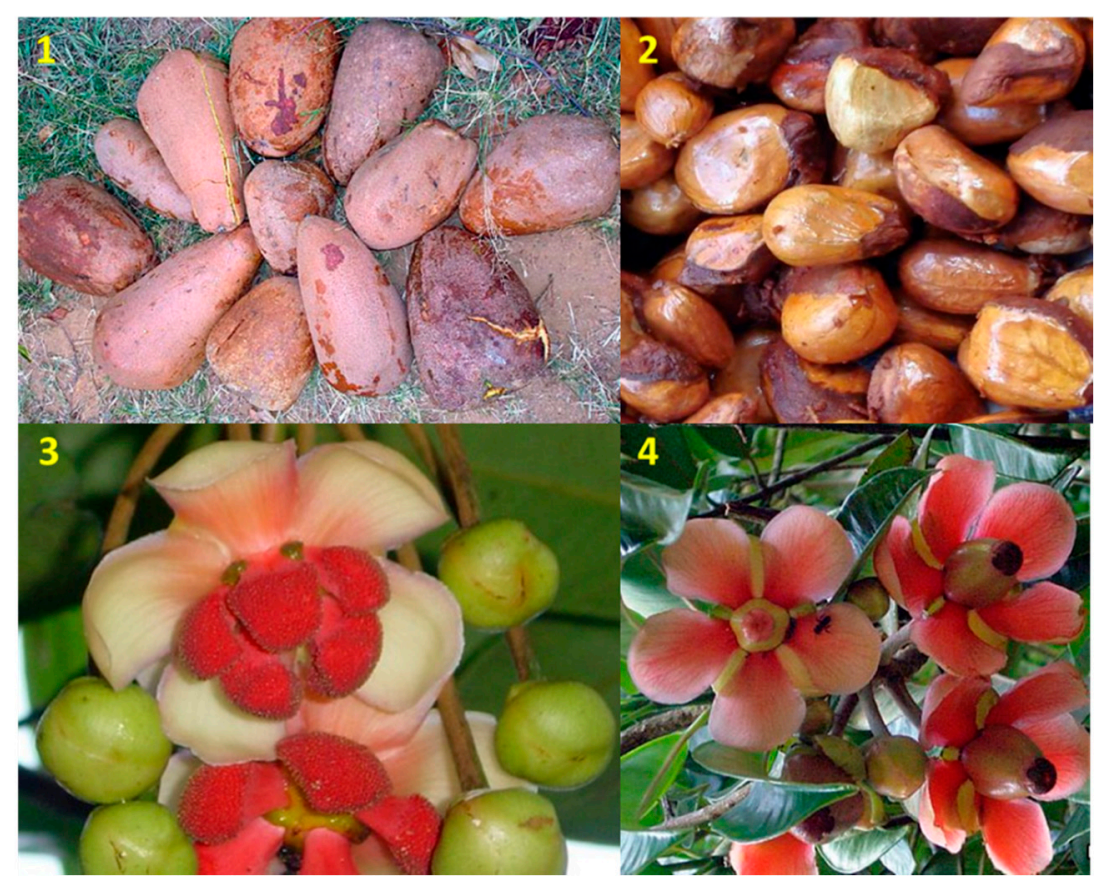

(b)

Figure 3. Line drawing detailing characteristic botanical features of (a) Allanblackia stuhlmannii (1, twig with male flowers; 2 , fruit; $\mathbf{3}$, seed; and $\mathbf{4}$, seed in cross section); and (b) photos of A. stuhlmannii (1, fruits; $\mathbf{2}$, seeds; $\mathbf{3}$, male flowers; and $\mathbf{4}$, female flowers). Line drawings reprinted with permission from: PROTA (Plant Resources of Tropical Africa/Ressources végétales de l'Afrique tropicale), Wageningen, Netherlands. http://www.prota4u.org; photos taken by M. Munjunga reprinted with permission from: ICRAF (World Agroforestry Centre), East \& Southern Africa Regional Programme, Dar-es-Salaam, Tanzania. http://www.worldagroforestry.org.

Proper botanical identification of the species used as a source of Allanblackia seeds is important when considering the use of the seed oil as a functional food or an ingredient in food products. Only when oil derived from the correct plant species and plant part (unadulterated) is used can the product be deemed safe for human consumption and assessed as to whether it has the chemical constituency that it claims. Many data are still lacking for species of Allanblackia that could be collected using identification methods such as macroscopic, microscopic, organoleptic, thin-layer chromatography (TLC), high-pressure (HP) TLC, HP liquid chromatography (HPLC) and Fourier transform infrared spectroscopy, all of which are commonly used in the quality control of botanical ingredients. Although domestication projects are ongoing to establish the sustainable cultivation of these species in tropical Africa, the steadily growing demand for Allanblackia seed oil has resulted in increased harvesting pressures on wild populations of Allanblackia species and, in turn, increased the risk of misidentification and/or adulteration. 
Table 1. Botanical characteristics of three species of Allanblackia of commercial interest [10-12].

\begin{tabular}{|c|c|c|c|}
\hline Species & A. floribunda & A. parviflora & A. stuhlmannii \\
\hline $\begin{array}{c}\text { Mature } \\
\text { height/Trunk } \\
\text { Diameter } \\
\end{array}$ & $30 \mathrm{~m} / 80 \mathrm{~cm}$ & $25(-33) \mathrm{m} / 80 \mathrm{~cm}$ & $35(-45) \mathrm{m} / 65 \mathrm{~cm}$ \\
\hline Outer bark & Reddish-brown to blackish; scales small and irregular & Yellowish-brown or reddish-brown; scales small and irregular & Dark grey to black, smooth or rarely flaking with square scales \\
\hline Inner bark & Granular, reddish or brown, exuding clear sap & $\begin{array}{c}\text { Reddish-brown with sometimes pale yellow streaks; } \\
\text { exuding colorless or pale yellow sap }\end{array}$ & $\begin{array}{l}\text { Red to pale brown with white stripes, fibrous to granular, } \\
\text { exuding a clear sap that turns yellowish upon oxidation }\end{array}$ \\
\hline Leaves & $\begin{array}{l}\text { Opposite, simple, entire, glabrous, estipulate; blade elliptical } \\
\text { to ovate, rarely obovate; base rounded or cuneate; } \\
\text { apex acuminate; } 8-25 \mathrm{~cm} \times 3-8 \mathrm{~cm} \text {; petiole } 1 \mathrm{~cm}\end{array}$ & $\begin{array}{l}\text { Opposite, simple, entire, glabrous, estipulate; blade } \\
\text { elliptical to narrowly obovate; base cuneate; apex } \\
\text { acuminate; } 12-25 \mathrm{~cm} \times 5-9 \mathrm{~cm} \text {; petiole } 1-1.5 \mathrm{~cm} \text {. }\end{array}$ & $\begin{array}{l}\text { Opposite, simple, entire, estipulate; blade oblong to } \\
\text { elliptical-oblong; base cuneate, apex shortly } \\
\text { acuminate; } 5-20 \mathrm{~cm} \times 1-7 \mathrm{~cm} \text {; petiole } 1-2 \mathrm{~cm}\end{array}$ \\
\hline Inflorescence & $\begin{array}{l}\text { Terminal raceme or panicle with strongly reduced } \\
\text { branches or flowers single or in pairs in leaf axils }\end{array}$ & $\begin{array}{l}\text { Terminal raceme or panicle with strongly reduced } \\
\text { branches or flowers single or in pairs in leaf axils }\end{array}$ & $\begin{array}{l}\text { Flowers solitary in leaf axils or } \\
\text { crowded at the end of branches }\end{array}$ \\
\hline Flowers & $\begin{array}{l}\text { Unisexual, regular, five-merous, } \\
\text { pinkish or reddish (rarely white); pedicel } 3-8 \mathrm{~cm}\end{array}$ & $\begin{array}{l}\text { Unisexual, regular, five-merous, pinkish } \\
\text { or reddish, fragrant; pedicel } 1-3 \mathrm{~cm}\end{array}$ & $\begin{array}{l}\text { Unisexual, regular, five-merous, cream to reddish, } \\
\text { fragrant; pedicel (3.5-) } 6.5-8 \mathrm{~cm}\end{array}$ \\
\hline Sepals & $\begin{array}{l}\text { Orbicular, unequal, outer ones } 5-8 \mathrm{~mm} \text { in diameter, } \\
\text { inner ones } 12-15 \mathrm{~mm} \text { in diameter, glabrous }\end{array}$ & Ovate or obovate, unequal, $6-18 \mathrm{~mm} \times 4-15 \mathrm{~mm}$, glabrous & $\begin{array}{l}\text { Orbicular to ovate, unequal, outer ones } 4-9 \mathrm{~mm} \text { in } \\
\text { diameter, inner ones } c a .2 \mathrm{~cm} \text { in diameter, pale yellow }\end{array}$ \\
\hline Petals & Obovate to orbicular, $20-25 \mathrm{~mm}$ long, glabrous & Obovate, $c a .20 \mathrm{~mm}$ long, glabrous & Orbicular to spathulate, $27-37 \mathrm{~mm} \times 18-26 \mathrm{~mm}$, glabrous \\
\hline Stamens & $\begin{array}{l}\text { Numerous, in } 5 \text { bundles opposite the petals, } 10-15 \mathrm{~mm} \\
\text { long, anthers arranged on the internal face of the bundle; } \\
\text { disk star-shaped with deeply folded glands }\end{array}$ & $\begin{array}{l}\text { Numerous, in five bundles opposite the petals, obtriangular, } \\
\text { ca. } 18 \mathrm{~mm} \text { long, anthers arranged on the internal face of } \\
\text { the bundle; disk star-shaped with smooth or slightly folded glands }\end{array}$ & $\begin{array}{l}\text { Numerous, in five bundles opposite the petals, } \\
\text { ca. } 2 \mathrm{~cm} \text { long, inner surface angled, anthers arranged } \\
\text { on the } 2 \text { faces of the bundles; disk star-shaped }\end{array}$ \\
\hline Ovary & $\begin{array}{l}\text { Superior, incompletely five-celled, stigma sessile, } \\
\text { staminal bundles reduced to a few free } 4-5 \mathrm{~mm} \\
\text { long staminodes, disk glands grooved } \\
\end{array}$ & Superior, incompletely five-celled, stigma sessile & $\begin{array}{l}\text { Superior, incompletely five-celled, stigma sessile; staminal } \\
\text { bundles reduced to a few free, } c a .4 \mathrm{~mm} \text { long staminodes }\end{array}$ \\
\hline Fruit & $\begin{array}{l}\text { Large ellipsoid berry } 20-50 \mathrm{~cm} \times 5-14 \mathrm{~cm} \text {, } \\
\text { with five longitudinal ridges, } 40-80 \text { seeded }\end{array}$ & $\begin{array}{l}\text { Large ellipsoid berry } 10-50 \mathrm{~cm} \times c a .15 \mathrm{~cm} \text {, with five longitudinal } \\
\text { ridges, brown warty appearance, } 40-100 \text { seeded }\end{array}$ & $\begin{array}{l}\text { Large oblong to globose or cone-shaped berry } \\
16-34 \mathrm{~cm} \times 15-17 \mathrm{~cm}, 2.5-6 \mathrm{~kg} \text {, red-brown, } 60-140 \text { seeded }\end{array}$ \\
\hline Seeds & $\begin{array}{c}\text { Ovoid, } 2.5-3 \mathrm{~cm} \times 1.5-2 \mathrm{~cm} \text {, enclosed in a pinkish aril; } \\
\text { embryo small, embedded in oily endosperm }\end{array}$ & Ovoid, $c a .3 \mathrm{~cm} \times 2 \mathrm{~cm}$, enclosed in a pinkish aril & $\begin{array}{l}\text { 4-Angular, } c a .4 \mathrm{~cm} \times 2-3 \mathrm{~cm} \text {, one angle with a small } \\
\text { fleshy aril; embryo small, embedded in oily endosperm }\end{array}$ \\
\hline Germination & Seedling with hypogeal germination & Seedling with hypogeal germination; epicotyl $4-5 \mathrm{~cm}$ long & Seedling with hypogeal germination \\
\hline
\end{tabular}




\subsection{Traditional Allanblackia Seed Oil Use}

By the late 19th century, well-established colonial empires such as France, Britain, Belgium and Portugal had already laid claim to large areas of Africa, while developing imperial powers such as Germany and Italy had followed suit on a smaller scale. Colonial powers invested significant efforts in-among other things-the exploration and exploitation of the new colonies as sources of raw materials for European industry [13]. Many alternative oil seeds were identified and studied, in particular by French, Belgian, and Italian institutions conducting research for their colonies in Central Africa, in part to provide the colonies with information about local plants that could be used for food and energy production. During the Great War, Allanblackia oil was used as a substitute for cocoa butter during the manufacture of chocolate [14].

The traditional use of the Allanblackia seed oil has been reported for Allanblackia floribunda (vegetable tallow tree, Kisidwe nuts), A. stuhlmannii (kagne butter), A. ulugurensis (kagne butter), and A. parviflora (vegetable tallow tree) [10-12,15] (Proto). Uses for Allanblackia oil vary according to the region in which the species occur. In West Africa, in parts of Ghana, Tanzania, Nigeria, and Sierra Leone, the seeds of various Allanblackia species (especially A. parviflora and A. floribunda) occurring in the region have been traditionally collected by local communities for food (e.g., for the production of cooking oil), and more recently, to produce soap [16,17]. After the seeds are ground and pressed to extract the oil, the bitter seedcake can be used as a protein-rich animal feed [18]. The frequency of traditional use of Allanblackia oil, however, has decreased over the last 50 years due to the availability of other commercially available oils. The seeds have a substantial value due to the high nutritional value of the oil, as well as its unique physical properties, which are similar in some ways to those of the oil obtained from the seed kernels of the African oil palm (Elaeis guineensis Jacq.), but production on a commercial scale had not been attempted until recently $[19,20]$.

After decolonization in Africa, the research efforts to discover new, alternative oilseeds continued. In the 1970s and 1980s, the seed oil from Allanblackia fruits harvested in the East Usambara Mountains in Tanzania was exported to Europe in small, but significant quantities [14]. In the 1980s, research efforts were supported by members of the African Safou Network (ASANET), which was initiated in 1980 to conserve indigenous fruit tree genetic resources, and which attempted to establish a market for the seed oil of the Safou or Atanga tree (Dacryodes edulis, Burseraceae) [21]. During this time, the researchers observed that some of these alternative seed oils were used for food or integrated into locally-sold cosmetics and/or medicines, and in some cases, regional or international markets existed [22].

The seed oil of $A$. parviflora is being developed as a rural based enterprise in Ghana, Nigeria, Cameroon, and Tanzania [23]. Currently, the "Novella Africa Project", which involves the corporate entity Unilever PLC (public limited company) and several African research agencies, farmers and NGOs (non-governmental organizations) working towards the development of high-quality consumer products for household use. Through their investments, Unilever PLC has created a stable market for the oil, and this is predicted to expand into a new African industry with a market value exceeding \$100 million [24]. In 2007, the European Food Safety Authority deemed Allanblackia seed oil (described as oil derived from the seeds of $A$. floribunda and/or A. stuhlmannii) as being acceptable for human consumption under specified conditions when included in "yellow fat and cream-based spreads". The food products that contain Allanblackia seed oil include vegetable-based dairy products, ice cream, and spreads [25]. 
It should be noted, however, that some of the concerns mentioned in Section 2.1 also apply here. The ESFA (European food safety authority) recommended that only species of Allanblackia that had been subjected to toxicological studies should serve as sources of raw materials for the seed oil production, but due to the continued prevalence of wildcrafting of materials in some regions and the absence of quality control parameters for many of these species, this recommendation may not always be followed. The samples analyzed by the ESFA were derived from only two species of Allanblackia and, thus, did not represent the full species diversity to be found in the tropical rain forests in various geographic regions of Africa.

Results from detailed, systematic, comparative analyses of the chemical composition of seeds from species of Allanblackia have not been made publically available. In their application to include Allanblackia seed oil in vegetable-based spreads, submitted in 2004, Unilever Deutschland GmbH indicated that some batches of the unrefined seed oil contained benzophenone derivatives (i.e., guttiferone $\mathrm{E}$ and $\mathrm{F}$ ), which could be removed by additional refining processes [26]. The latter compound induces cellular apoptosis and has been reported as a constituent of A. stuhlmannii roots [27]. With respect to the use of Allanblackia oil as a functional food, therefore, this information serves as evidence that at least the unrefined seed oil contains bioactive secondary metabolites that could exert pharmacological effects. Further in vitro and in vivo studies are needed, however, to fully investigate the extent of this bioactivity.

\subsection{Cultivation and Wildcrafting of Allanblackia Seeds}

As mentioned above, it is crucial to gather information about the origin of plant-based fats and oils, since both genetic and environmental factors influence aspects of production and trade. Allanblackia trees that have been planted for the commercial production of seed oil need significant time to mature, usually seven years or more, before they produce an economic crop, and due to the dioecious nature of the plants, obviously a crop will only be obtained from (productive) female plants. In general, tree crop yields can be affected by seasonal climatic changes, as well as environmental factors such as the use of herbicides, fungicides, or pesticides (e.g., at the moment, only sprayed on seeds prior to planting) and additional advantage is that tree crops grown in tropical Africa can be harvested year-round, although the levels of seasonal qualitative and quantitative variation have yet to be determined for several regions and species $[23,28]$.

The FAO had already identified Allanblackia as a crop of high potential interest in 1992, due to the potential for the seed oil (which was listed as a non-edible oil at that time) to become a profitable and sustainable raw material, the development of which could benefit rural communities [29]. Several studies and surveys have been conducted in recent years to assess the socioeconomic progress associated with the establishment of a supply chain for Allanblackia oil [20,30,31]. Currently, Allanblackia seed (e.g., from A. floribunda, A. parviflora, A. stuhlmannii) is usually collected in the wild or from trees that have been preserved on farm land (trees retained to provide shade for animals and other crop plants, when clearing land for cultivation) for use in cultivation [20,23].

Since the establishment of the "Novella Africa Project" in 2002, significant advances in knowledge about the natural distribution of the most common Allanblackia species, as well as their production potential, biology, and ecology have been made. Jamnadass et al. [32] and references therein described 
the coordinated strategies that had been undertaken up until 2010 to domesticate Allanblackia trees in such a way as to address both the demands of the market and the varied challenges posed by cultivation and conservation. In addition, more recent studies on seed germination and propagation, sex determination of individuals, population biology, and genetic diversity for selected species in specific geographic locations have been carried out [33,34]. In particular, results of molecular analyses with respect to amplified fragment length polymorphisms (AFLP) have indicated that this method may be useful to differentiate among species, especially when vegetative material only is available for collection in regions where more than one species of Allanblackia occur, and that the high levels of AFLP variation suggest useful domestication opportunities [34]. Much data is still lacking, however, for entire species, and significant gaps in the data exist even for the more common species of Allanblackia with respect to their reproductive biology, propagation, cultivation, selection, and breeding, which need to be addressed through targeted research.

\subsection{General Characteristics of the Seed Oil}

Like many commonly-used vegetable oils, Allanblackia oil consists of well-known triglycerides. Because it contains tocopherol as a minor constituent, it has good storage stability characteristics. Due to its chemical composition and relatively high melting point ( $c .34{ }^{\circ} \mathrm{C}$ ), it can be used to improve the consistency of cocoa butter substitutes, margarine spreads, and other vegetable-based dairy products. The fact that it does not require additional transformation to acquire the desired characteristics is an added advantage. As in the case of other oils, Allanblackia oil can be combined with other oils or fats to achieve specific physical properties. When analyzing the saturated fatty acids (SFAs), the high stearic acid content (45\%-58\% on average) and comparatively low palmitic acid content can be used to chemically distinguish Allanblackia oil from palm and palm kernel oils [25].

Allanblackia seed oil shares some characteristics with shea butter (from the seeds of Vitellaria paradoxa C.F.Gaertn. (Sapotaceae)), making it a valuable and useful raw material in both the food and cosmetic industries. The triglyceride composition of the seed oil indicates that, given the existence of a stable supply chain, Allanblackia oil can potentially serve as an alternative in many food and cosmetic products to palm oil, cocoa butter, and shea butter. When considering the implications of the use of Allanblackia seed oil as a functional food or functional food component, it is important to keep in mind that individual SFAs have different effects on blood cholesterol levels. Stearic acid is unique in that, unlike other long chain SFAs ( $>10$ carbons), human and animal studies with shea butter and cocoa butter have demonstrated that stearic acid does not alter the levels of total low density lipoprotein (LDL, or "bad" cholesterol) and high density lipoprotein (HDL, or "good" cholesterol) measured in the blood of adults. Other long chain SFAs that often predominate in plant-based oils, including lauric (C12:0), myristic (C14:0), and palmitic (C16:0) acids, lead to increases in blood cholesterol levels and correspondingly increase the risk of the development of cardiovascular disease, unlike stearic acid [35-37]. These results indicate that including fats and oils (or functional foods containing these) that are rich in stearic acid, as opposed to other SFAs, in the diet could be advantageous, particularly for hypercholesterolemic individuals [38]. 


\subsubsection{Allanblackia floribunda Seed Oil}

An early study of $A$. floribunda seed oil reported that the fatty acid constituents were made up of primarily stearic acid (56.8\%) and oleic acid (39.4\%), followed by minor amounts of palmitic acid (3.2\%), linoleic acid (0.4\%), and eicosanoic acid (0.2\%). Triglyceride components consisted mostly of 2-oleostearin (76.2\%), 1-stearo-diolein (15.5\%), and 2-oleopalmitostearin (5\%) [39]. In a more recent study, in which seeds collected from seven individuals of $A$. floribunda growing in the Congo were extracted via Soxhlet extraction (cyclohexane), a yield of $60 \%-65 \%$ oil $(w / w)$ was obtained. This seed oil consisted primarily of a saturated fatty acid (stearic acid, 61\%-63\%) and a monounsaturated fatty acid (oleic acid, 35\%-36\%) [22]. Another study, in which A. floribunda seeds were collected from trees occurring in Cameroon, ground and extracted using a Soxhlet extraction (hexane) technique, revealed that the seeds contained $62.5 \%$ oil $(w / w)$ and $6.7 \%$ ash. The oil, examined with gas chromatography, consisted of $62.6 \%$ of saturated fatty acids $(61.3 \%$ of which were stearic acid) and $36.7 \%$ of monounsaturated fatty acids (of which $36.6 \%$ were oleic acid), as well as $0.7 \%$ polyunsaturated fatty acids [40]. Analyses of seeds collected from A. floribunda trees growing in Nigeria yielded similar results, demonstrating that the seeds contained on average $60.4 \%$ oil, $1.7 \%$ ash, $4.1 \%$ fiber, and $32.6 \%$ carbohydrates. Positive chemical reactions that indicated the presence of minor amounts of alkaloids, flavonoids, saponins, and tannins were observed, although it must be noted that these results must be confirmed by alternative methods (e.g., TLC, HPLC), since false positive test results can occur with the methods described [41].

While few studies have thus far been conducted to examine intra- and interpopulation differences in Allanblackia seed oil yield and composition, one such study in which 17-40 fruits were sampled from each of $70 \mathrm{~A}$. floribunda trees growing wild at four sites from within the natural range of the species in Cameroon revealed that the fatty acid content of the seeds ranged from $44.2 \%-66.1 \%$ (stearic acid) and $25.0 \%-48.4 \%$ (oleic acid) among tree samples. Significant tree-to-tree variation in the mass of the fruits, number of seeds in each fruit, and chemical constituents of the seed oil were observed [42]. On one hand, these results allowed the researchers to identify a potential breeding population (trees that produced seeds with desired characteristics), but on the other hand, the high degree of variation in both physical and chemical properties of the fruits and seeds of the wild A. floribunda trees highlights some of the inherent problems encountered when attempting to establish a steady supply chain of high-quality Allanblackia oil from seeds collected in the wild.

The optimum conditions for the extraction of seed oil from several species of Allanblackia have yet to be determined. One study, however, has been conducted with A. floribunda seeds to determine the optimum extraction conditions and assess both the quality and stability of the oil obtained from crude pressing methods and from solvent extraction. In this study, the seed samples were milled under different temperature regimes and moisture levels, and the oil was either expressed by use of a manual screw press or a Soxhlet apparatus (solvent: petroleum ether). The oil yield obtained from solvent extraction was higher than from the manual expression $(67.6 \%$ vs. $48.6 \%$, respectively), but the quality parameters measured such as the melting point, acid value, ester value, iodine value, peroxide value, refractive index, specific gravity, and saponification value showed no significant differences between the oils. The pressed oil, however, due to significant differences in the peroxide value and free fatty acid content, was more stable when stored in plastic containers as compared to the oil extracted with solvent [43]. 
While the quality parameters of the expressed or extracted oil are of particular importance, the toxicological and environmental aspects of seed oil extraction also require consideration. The use of hot water as an extraction solvent, due to its low cost, toxicity, and environmental impact, was investigated as a method of extracting oil from A. floribunda seeds. An extraction yield of $42.2 \%$ oil $(w / w)$ from the seeds and extraction efficiency of 58.6\% was reported by Alenyorege et al. [44], indicating that this method could be applied to meet commercial, industrial, and domestic demands.

\subsubsection{Allanblackia parviflora Seed Oil}

The seed oil from $A$. parviflora has been shown to be quite similar to that from $A$. floribunda. An early study of the fatty acid components of $A$. parviflora revealed them to be primarily stearic acid (51.6\%) and oleic acid (43.9\%), with minor amounts of myristic acid (1.8\%), palmitic acid (2.5\%), and eicosanoic acid $(0.2 \%)$. The major triglyceride component were determined as 2-oleostearin $(60.1 \%)$, 1-stearo-diolein (26.9\%) and 2-oleopalmitostearin (6.9\%) [39]. A study conducted on seeds of A. parviflora growing in Ghana, from which oil was extracted by either the use of a screw press or Soxhlet extraction (petroleum ether), yielded an average of $68 \%$ oil $(w / w)$. The fatty acid composition of the seed oil was determined by gas chromatography as $2.9 \%$ palmitic acid, $52.3 \%$ stearic acid, and $44.8 \%$ oleic acid. Secondary metabolites belonging to the classes of carotenoids, terpenes, saponins, or tannins were not detected in the oil in this study. Nutritional analyses indicated that the seeds contained $4.3 \%$ protein, $2.0 \%$ ash, $5.7 \%$ crude fiber, and $17.1 \%$ carbohydrates [16]. These values were generally lower than those reported for shea kernels and cocoa beans, but the energetic value of Allanblackia seeds was $2863.44 \mathrm{~kJ} / 100 \mathrm{~g}$ (exceeding both that of shea kernels and cocoa beans), supporting the traditional consumption of these seeds as a high-energy snack in some parts of Africa [11].

\subsubsection{Allanblackia stuhlmannii Seed Oil}

A triglyceride derived from three molecules of stearic acid (2-oleostearin) was first isolated by crystallization from $A$. stuhlmannii seed oil in 1896, in amounts that were even remarked upon as being impressive at the time [45]. The seed oil of A. stuhlmannii displays some similarities to that of A. floribunda and A. parviflora. The edible oil is solid at room temperature (melting point $(\mathrm{mp})=34^{\circ} \mathrm{C}$ ) and, in Tanzania, is referred to by the common names "Allanblackia fat" or "kanye butter" [46]. Due to its physical properties and neutral taste, it is used in cooking. The seeds have been reported contain ca. $50 \%$ oil $(w / w)$, the fatty acid composition of which consists mainly of stearic acid $(45 \%-58 \%)$ and oleic acid (40\%-51\%) [12].

\subsubsection{Other Allanblackia Seed Oils}

The seed oils of two species of Allanblackia occurring in Cameroon, A. gabonensis and A. stanerana, have been examined, whereby the oil was extracted through maceration of the ground seeds with hexane. The seeds of $A$. gabonensis were demonstrated to yield $68.2 \%$ oil ( $w / w)$, which contained $5.35 \%$ water and $60.6 \%$ saturated, $37.6 \%$ monounsaturated, and $0.8 \%$ polyunsaturated fatty acids, of which the $\mathrm{C} 18: 0$ and C18:1 types dominated. The seeds of A. stanerana, meanwhile, yielded $69.9 \%$ oil $(w / w)$, which contained $22.0 \%$ water and $70.9 \%$ saturated, $28.2 \%$ monounsaturated, and $0.8 \%$ polyunsaturated fatty 
acids, and again, the C18:0 and C18:1 types dominated. The quality parameters, namely the acid index, iodine index, and refractive index values, were similar for these two oils, although the former two parameters were higher for A. gabonensis and the latter parameter, higher for A. stanerana. In both seed oils, the primary saturated fatty acid was stearic acid (60.1\% and 69.6\%, respectively), while the major monounsaturated fatty acid was oleic acid (37.4\% and $28.1 \%$, respectively [47]. The seed oils of A. kimbiliensis, A. kisonghi, A. marienii and A. ulugurensis have not yet been subjected to physicochemical or phytochemical analyses to this author's knowledge.

\subsection{Phytochemistry and Medicinal Use of Allanblackia Seeds}

In western Africa, decoctions of the leaves and bark of $A$. floribunda are used to treat toothache, dysentery, and hypertension and the crushed plant material or extracts is applied topically as an analgesic. Specific medicinal applications for the seeds, however, in the traditional medicinal systems found in this region, and no bioactive secondary metabolites have yet been isolated from the plant [48]. In Tanzania, various parts of $A$. stuhlmannii are used in the traditional medicine; the leaves are chewed to treat coughs, a leaf tea is drunk to treat chest pain, and extracts of the roots, bark, and leaves are taken to treat impotence. Interestingly, the heated oil extracted from the seeds is used as a liniment to treat rheumatism, rubbed into sore joints, or dabbed on wounds and rashes [49]. The Hehe people, native to south-central Tanzania, have been reported to combine the seed oil with crushed seeds of Psorospermum febrifugum Spach (Hypericaceae) and rub the mixture into the soles of the feet to heal deep cracks [46]. Although no phytochemical investigations of $A$. stuhlmanniii seeds have yet been conducted, the seeds of Psorospermum febrifugum have been shown to contain numerous bioactive xanthones [50].

Interestingly, a xanthone derivative (allanxanthone E), several xanthones (1,7-dihydroxy-3-methoxy2-(3-methylbut-2-enyl)xanthone; $\alpha$-mangostin; garciniafuran; allanxanthone $\mathrm{C}$; and 1,6-dihydroxy-2,4diprenylxanthone) and two triterpenes (friedelin and lupeol) have been isolated from the seeds of Allanblackia gabonensis (cited under the synonym A. monticola Mildbr. ex Engl.), which is widely distributed in western Cameroon. This species is used in the local traditional medicine to treat diarrhea, fever, pain, respiratory infections, and toothache. $\alpha$-mangostin was shown to possess apoptotic and antiproliferative activity against ESKOL cells derived from a hairy cell leukemia patient and leukemia cells freshly isolated from B-CLL patients when tested in concentrations as low as $2.4 \mu \mathrm{M}$. Allanxanthone E, 1,7-dihydroxy-3methoxy-2-(3-methylbut-2-enyl)xanthone, and $\alpha$-mangostin triggered apoptosis in B-CLL leukemia cells in a dose-dependent manner, whereby the latter compound was the most potent [51].

These results are significant when considering the inclusion of Allanblackia oils in functional foods, especially unrefined oils and particularly those that have been extracted using solvents with intermediate polarity. As shown for the case of the benzophenone derivatives, guttiferone $\mathrm{E}$ and $\mathrm{F}$ (Section 2.2), bioactive secondary metabolites can be co-extracted along with primary metabolites such as triacylglycerols and fatty acids from the seeds of Allanblackia. When ingested, these phytochemicals have the potential to act as pharmacological agents, and could prevent the development of or be used to treat chronic disease. This said, very few studies to date have carefully examined either manually expressed or solvent extracted Allanblackia seed oils for the presence, identity and/or quantity of potentially bioactive secondary metabolites, and this is both an interesting and important direction for future research. 


\section{Conclusions}

Species of the genus Allanblackia (Clusiaceae) are currently the focus of a high degree of attention, due to interest in the consumption and commercial exploitation of the seed oils. The steadily increasing demand for alternative, plant-based oils and fats and the favorable physicochemical characteristics of Allanblackia seed oils (with up to $95 \%$ combined stearic and oleic acid) have led to its inclusion as an ingredient in functional food products, including vegetable-based dairy products, ice cream, and spreads. While domestication projects are underway to establish the sustainable cultivation of several Allanblackia species in tropical Africa, the steadily growing demand for the seed oil has resulted in increased harvesting pressures on wild populations of Allanblackia species and, in turn, increased the risk of misidentification and/or adulteration. Proper botanical identification of the species used is important, since only authenticated oil can be deemed safe for human consumption when included in functional food products.

In terms of its nutritional value, Allanblackia oil can be combined with other oils or fats to achieve specific physical properties. The high stearic acid content (ranging, according to the species, between $44 \%-66 \%$ ) and comparatively low palmitic acid content of the oil is relevant because stearic acid has not been demonstrated to alter the plasma levels of total low density lipoprotein (LDL, or "bad" cholesterol) and high density lipoprotein (HDL, or "good" cholesterol), unlike palmitic acid. Functional food products containing Allanblackia oil, therefore, could be considered to have health advantages over products containing oils with higher levels of lauric, myristic, and/or palmitic acids, the ingestion of which has been shown to lead to increases in blood cholesterol levels. Such considerations may be particularly important for individuals at greater risk of cardiovascular disease or who have hypercholesterolemia.

Information available about the chemical constituency of Allanblackia seed oils, the roles of the component phytochemicals in preventive strategies (e.g., associated with increased intake as part of a healthy diet), or the role of these compounds as pharmacological agents used in the treatment of chronic disease was examined in this review. The phytochemistry of the seed oils of nearly all Allanblackia species is poorly known, particularly with regard to the presence and/or content of lipophilic secondary metabolites. Unrefined seed oils from Allanblackia have been shown to contain bioactive secondary metabolites (i.e., benzophenone derivatives, xanthones), which may have the potential to act as pharmacological agents when ingested. Phytochemical investigations of Allanblackia seed oils for the presence, identity and/or quantity of potentially bioactive secondary metabolites, and pharmacological testing of isolated compounds represent important directions for future research.

\section{Acknowledgments}

The author sincerely thanks Gaby Schmelzer (PROTA (Plant Resources of Tropical Africa/ Ressources végétales de l'Afrique tropicale), Wageningen, The Netherlands) and Moses Munjunga (ICRAF (World Agroforestry Centre), East \& Southern Africa Regional Programme, Dar-es-Salaam, Tanzania) for granting permission for selected maps, line drawings, and photos to be reprinted in this publication, and acknowledges the Institute of Pharmaceutical Sciences, University of Graz for providing a supportive work environment. 


\section{Conflicts of Interest}

The author declares no conflict of interest.

\section{References}

1. Gunstone, F. Production and trade of vegetable oils. In Vegetable Oils in Food Technology: Composition, Properties and Uses, 2nd ed.; Gunstone, F., Ed.; Blackwell Publishing Ltd.: Chichester, UK, 2011; pp. 1-24.

2. Da Silva, F.J.; de Lima, A.G.B.; da Costa, Y.J.R.; Rilho, C.R.B.; Grilo, M.B. Duel-fuel (natural gas/biodiesel) engines: Fundamentals, performance and environmental impact. In Alternative Energies: Updates on Progress; Ferreira, G., Ed.; Springer-Verlag: Berlin, Germany, 2013; pp. 47-68.

3. Betoret, E.; Betoret, N.; Vidal, D.; Fito, P. Functional foods development: Trends and technologies. Trends Food Sci. Technol. 2011, 22, 498-508.

4. WHO. Diet, nutrition and the prevention of chronic diseases. Available online: http://www.fao.org/ docrep/005/AC911E/AC911E00.HTM\#Contents (accessed on 29 June 2015).

5. Stevens, P. Clusiaceae-Guttiferae. In The Families and Genera of Vascular Plants IX. Flowering Plants Eudicots; Kubitzki, K., Ed.; Springer Verlag: Berlin, Germany, 2007; pp. 48-66.

6. Sweeney, P.W. Phylogeny and floral diversity in the genus Garcinia (Clusiaceae) and relatives. Int. J. Plant Sci. 2008, 169, 1288-1303.

7. Ruhfel, B.R.; Bittrich, V.; Bove, C.P.; Gustafsson, M.H.G.; Philbrick, C.T.; Rutishauser, R.; Xi, Z.; Davis, C.C. Phylogeny of the clusioid clade (Malpighiales): Evidence from the plastid and mitochondrial genomes. Am. J. Bot. 2011, 98, 306-325.

8. Hernandez, E.M.; Kamal-Eldin, A. Cosmetic and pharmaceutical properties of fats and oils. In Processing and Nutrition of Fats and Oils; Erickson, D., Ed.; John Wiley \& Sons, Ltd.: Chichester, UK, 2013.

9. Bamps, P.; Robson, N.; Verdcourt, B. Flora of Tropical East Africa: Guttiferae; Crown Agents: London, UK, 1978.

10. Orwa, C.; Munjuga, M. Allanblackia floribunda Oliv. In PROTA 14: Vegetable oils/Oléagineux; van der Vossen, H.A.M., Mkamilo, G.S., Eds.; PROTA: Wageningen, The Netherlands, 2007.

11. Orwa, C.; Oyen, L.P.A. Allanblackia parviflora A.Chev. In PROTA 14: Vegetable oils/Oléagineux; van der Vossen, H.A.M., Mkamilo, G.S., Eds.; PROTA: Wageningen, The Netherlands, 2007.

12. Munjuga, M.; Mwaura, L.; Schmidt, L.H. Allanblackia stuhlmannii Engl. Seed Leaflet. Available online: http://www.prota4u.org (accessed on 20 June 2015).

13. Pakenham, T. The Scramble for Africa; Weidenfeld \& Nicolson: London, UK, 1991; pp. 1876-1912.

14. Pye-Smith, C. Seeds of Hope: A Public-Private Partnership to Domesticate a Native Tree, Allanblackia, Is Transforming Lives in Rural Africa; World Agroforestry Centre: Nairobi, Kenya, 2009.

15. Ruffo, C.K.; Birnie, A.; Tengnäs, B. Edible wild plants of Tanzania; Regional Land Management Unit/SIDA: Nairobi, Kenya, 2002.

16. Adubofuor, J.; Sefah, W.; Oldham, J.H. Nutrient composition of Allanblackia paviflora seed kernels and oil compared with some plant fats and oils and application of the oil in soap preparation. J. Cereals Oil Seeds 2013, 4, 1-9. 
17. Hutchinson, J.; Dalziel, J.M.; Keay, R.W.J. Flora of West Tropical Africa; Crown Agents: London, UK, 1954.

18. Orwa, C.; Mutua, A.; Kindt, R.; Jamnadass, R.; Anthony, S. Agroforestree Database: A Tree Reference and Selection Guide Version 4.0, 2009. Available online: http://www.worldagroforestry.org (accessed on 20 June 2015).

19. Buss, C.; Tissari, J. Allanblackia-An ingredient for poverty reduction? Rural 21 2010, 3, 37-39.

20. Bürkle, E.; Palenberg, M. Allanblackia supply chain as a strategic alliance with Unilever R \& D Netherlands. Available online: http://www.entwicklung.at/uploads/media/ 7_Allanblackia_Supply_chain_as_a_Strategic_Alliance_with_Unilever_R_D_Netherlands_Tanza nia.pdf (accessed on 13 June 2015).

21. Silou, T. Oils and Fats for the Future. A Case Study: Safou (Dacryodes edulis) from the Congo Basin Countries in Africa; Nova Science Publishers: Hauppauge, NY, USA, 2012.

22. Loumouamou, B.W.; Binaki, A.F.; Silou, T. Oleaginous character and profiles in fatty acids and in triacylglycerols of the seeds of Allanblackia floribunda Oliv. of Congo. Adv. J. Food Sci. Technol. 2014, 6, 308-315.

23. Shrestha, R.B.; Akangaamkum, A.D.; Agyare, E.; Torpey, K.; Fordjor, M.M.; Hinneh, K.O. Relative attractiveness of Allanblackia cultivation in Ghana: Farmer's perceptions and willingness. Available online: http://www.snvworld.org/download/publications/2._relative_attractiveness_of_allanblackia_cultiv ation_in_ghana_farmers_perceptions_and_willingness.pdf (accessed on 10 September 2015).

24. Shrestha, R.B.; Akangaamkum, A.D. Novella Partnership, a Partnership for Poverty Reduction through Sustainable Enterprise Development Based on Allanblackia; SNV Ghana: Accra, Ghana, 2008.

25. Tetens, I. Opinion of the scientific panel on dietetic products, nutrition and allergies on a request from the commission related to the safety of Allanblackia seed oil for use in yellow fat and cream based spreads: Request N EFSA-Q-2007-059. Eur. Food Saf. Auth. 2007, 580, 1-10.

26. Li, X.; Lao, Y.; Zhang, H.; Wang, X.; Tan, H.; Lin, Z.; Xu, H. The natural compound guttiferone $\mathrm{F}$ sensitizes prostate cancer to starvation induced apoptosis via calcium and JNK elevation. BMC Cancer 2015, 15, 254-267.

27. Fuller, R.W.; Blunt, J.W.; Boswell, J.L.; Cardellina, J.H., Boyd, M.R. Guttiferone F, the first prenylated benzophenone from Allanblackia stuhlmannii. J. Nat. Prod. 1999, 62, 130-132.

28. Ofori, D.A.; Kehlenbeck, K.; Munjuga, M.; Asaah, E.; Kattah, C.; Rutatina, F.; Jamnadass, R. Allanblackia species: A model for the domestication of high potential tree crops in Africa. World Agrofor. Cent. 2011, doi:10.17660/ActaHortic.2013.979.32.

29. FAO (Food and Agriculture Organization of the United Nations). Minor Oil Crops. Part II-Non-Edible Oils. Available online: http://www.fao.org/docrep/x5043e/x5043E0d.htm\#Allanblackia (accessed on 8 July 2015).

30. Amanor, K.S. Allanblackia standard setting and sustainable supply chain management. Socioeconomic conditions of Allanblackia production and perceptions of farmers and collectors. Available online: http://worldagroforestry.org/projects/allanblackia/workshop/2006/supporting_material/Allanblack ia/Socioeconomic\%20issues\%20Ghana.pdf (accessed on 19 June 2015).

31. Andersson, M. Allanblackia nuts in tropical Africa: A new source for food, oil and ecosystem services. In Bundling Agricultural Products with Ecosystem Services: Incentives for Ecoagriculture Landscapes; Andersson, M.S., Scherr, S.J., Shames, S., Eds.; Ecoagriculturepartners: Washington, DC, USA, 2009. 
32. Jamnadass, J.; Dawson, I.K.; Anegbeh, P.; Asaah, E.; Atangana, A.; Cordeiro, N.J.; Hendrickx, H.; Henneh, S.; Kadu, C.A.; Kattah, C.; et al. Allanblackia, a new tree crop in Africa for the global food industry: Market development, smallholder cultivation and biodiversity management. For. Trees Livelihoods 2010, 19, 251-268.

33. Russell, J.R.; Kadu, C.A.C.; Jamnadass, R.; Booth, A.; Cordeiro, N.J.; Woodhead, M.; Dawson, I.K. AFLP and SSR diversity in the African fruit tree Allanblackia: Implications for management of a genus newly subject to domestication for the edible oil industry. Tree Genet. Genomes 2009, 5, 517-527.

34. Alvum-Toll, K. Allanblackia stuhlmannii-A tree under current domestication: What are the soil requirements? Available online: http://stud.epsilon.slu.se/5966/1/alvum-toll_k_130821.pdf (accessed on 1 July 2015).

35. Dougherty, R.; Allman, M.; Iacono, J. Effects of diets containing high or low amounts of stearic acid on plasma lipoprotein fractions and fecal fatty acid excretion of men. Am. J. Clin. Nutr. 1995, 61, 1120-1128.

36. Tholstrup, T.; Marckmann, P.; Jespersen, J.; Sandström, B. Fat high in stearic acid favorably affects blood lipids and factor VII coagulant activity in comparison with fats high in palmitic acid or high myristic and lauric acids. Am. J. Clin. Nutr. 1994, 59, 371-377.

37. Denke, M.; Grundy, S. Effects of fats high in stearic acid on lipid and lipoprotein concentrations in men. Am. J. Clin. Nutr. 1991, 54, 1036-1040.

38. Nestel, P.J.; Pomeroy, S.; Kay, S.; Sasahara, T.; Yamashita, T. Effect of a stearic acid-rich, structured triacylglycerol on plasma lipid concentrations. Am. J. Clin. Nutr. 1998, 68, 1196-1201.

39. Meara, M.L.; Zaky, Y.A.H. Fatty acids and glycerides of the seed fats of Allanblackia floribunda and Allanblackia parviflora. J. Soc. Chem. Ind. 1940, 59, 25-26.

40. Noumi, G.B.; Njine, C.B.; Pengou, M.S.; Ngameni, E. Physicochemical analysis of the Cameroonian Allanblackia floribunda Oliver seeds oil extract. Riv. Ital. Sostanze Grasse 2011, 88, 38-45.

41. Dike, M.C.; Asuquo, M.E. Proximate, phytochemical and mineral compositions of seeds of Allanblackia floribunda, Garcinia kola and Poga oleosa from Nigerian rainforest. Afr. J. Biotechnol. 2012, 11, 11096-11098.

42. Atangana, A.R.; van der Vlis, E.; Khasa, D.P.; van Houten, D.; Beaulieu, J., Hendrickx, H. Tree-to-tree variation in stearic and oleic acid content in seed fat from Allanblackia floribunda from wild stands: Potential for tree breeding. Food Chem. 2011, 126, 1579-1585.

43. Wilfred, S.; Adubofuor, J.; Oldham, J.H. Optimum conditions for expression of oil from Allanblackia floribunda seeds and assessing the quality and stability of pressed and solvent extracted oil. Afr. J. Food Sci. 2010, 4, 563-570.

44. Alenyorege, E.A.; Hussein, Y.A.; Adongo, T.A. Extraction yield, efficiency and loss of the traditional hot water flotation (HWF) method of oil extraction from the seeds of Allanblackia floribunda. Int. J. Sci. Technol. Res. 2015, 4, 92-95.

45. Heise, R. Über das Vorkommen des Oleodistearins in dem Fette der Samen von Theobroma-Cacao. Arbeiten aus dem Kaiserlichen Gesundheitsamte 1896, 12, 540. (In German)

46. Mwaura, L.; Munjuga, M. Allanblackia stuhlmannii (Engl.) Engl. In PROTA 14: Vegetable Oils/Oléagineux; van der Vossen, H.A.M., Mkamilo, G.S., Eds.; PROTA: Wageningen, The Netherlands, 2007. 
47. Pengou, M.; Noumi, G.B.; Ngameni, E. Fatty acid composition and some physicochemical properties of oils from Allanblackia gabonensis and A. stanerana kernels. J. Am. Oil Chem. Soc. 2013, 90, 27-32.

48. Bilanda, D.C.; Dimo, T.; Dzeufiet Djomeni, P.D.; Bella, N.M.; Aboubaka, O.B.; Nguelefack, T.B.; Tan, P.V.; Kamtchouing, P. Antihypertensive and antioxidant effects of A. floribunda Oliv. (Clusiaceae) aqueous extract in alcohol- and sucrose-induced hypertensive rats. J. Ethnopharmacol. 2010, 128, 634-640.

49. Meschak, C. Indigenous knowledge of Allanblackia stuhlmannii in the East Usambara Mountains, Tanzania. Available online: http://worldagroforestry.org/projects/allanblackia/Report/Tech/Ik_Tz.pdf (accessed on 28 June 2015).

50. Epifano, F.; Fiorito, S.; Genovese, S. Phytochemistry and pharmacognosy of the genus Psorospermum. Phytochem. Rev. 2013, 12, 673-684.

51. Azebaze, A.G.B.; Menasria, F.; Noumi, L.G.; Nguemfo, E.L.; Tchamfo, M.F.; Nkengfack, A.E.; Kolb, J.P.; Meyer, M. Xanthones from the seeds of Allanblackia monticola and their apoptotic and antiproliferative activities. Planta Med. 2009, 75, 243-248.

(C) 2015 by the authors; licensee MDPI, Basel, Switzerland. This article is an open access article distributed under the terms and conditions of the Creative Commons Attribution license (http://creativecommons.org/licenses/by/4.0/). 